\title{
Variation in Low-temperature Exotherms of Pecan Cultivar Dormant Twigs
}

\author{
Gayle M. Volk', John Waddell, and Leigh Towill \\ USDA-ARS National Center for Genetic Resources Preservation, U.S. \\ Department of Agriculture, Agricultural Research Service, 1111 S. Mason \\ Street, Ft. Collins, CO 80521
}

\section{L.J. Grauke \\ USDA-ARS Pecan Genetics and Breeding Research Unit, Route 2, Box 133, Somerville, TX 77879}

Additional index words. Carya illinoinensis, native distribution

\begin{abstract}
Pecan [Carya illinoinensis (Wangenh.) K. Koch] trees native to northern regions are more cold-tolerant than those native to and grown in the southern United States. To identify a possible assay for cold hardiness, dormant winter twigs from 112 diverse pecan cultivars grown in Texas were surveyed using differential thermal analyses (DTA). The low temperature exotherm (LTE) from DTA was identifiable when twigs were stored at $3{ }^{\circ} \mathrm{C}$ for up to $120 \mathrm{~d}$ after harvest. Thirty-nine percent of the southern pecan cultivars lacked an obvious LTE, and the remaining southern cultivars had an average LTE of $32.9^{\circ} \mathrm{C}$. In contrast, only $11 \%$ of the northern pecan cultivars lacked the LTE and the remaining cultivars had a significantly lower LTE of $-35.4^{\circ} \mathrm{C}$. Because twig samples were collected from trees grown in the same Texas orchard, it is suggested that there is a genetic component that affects the temperature of the LTE. Budbreak generally occurred earlier in southern cultivars than those that originated in the north. Both budbreak and LTE data can be correlated with regional origin; timing of budbreak may be preferred over DTA to predict relative cold hardiness in pecan.
\end{abstract}

Pecan [Carya illinoinensis (Wangenh.) K. Koch] trees are native to the United States and Mexico with a range that extends from floodplains in Illinois and Iowa through Texas to Mexico (Fig. 1). Trees originating from northern populations mature seeds within a growing season of $\approx 170 \mathrm{~d}$ and survive in areas that receive average annual minimum winter temperatures of -26 to $-29{ }^{\circ} \mathrm{C}$. Trees at the southern extent of the range in Oaxaca, Mexico, may experience no freezing temperature in some years and new growth occurs before dehiscence of the previous season's foliage (Grauke and Thompson, 2008). Observations of seedlings from across the range, grown in a common orchard, allow native populations to be divided into two main provenances. Seedlings originating from southern sources (from Texas south) break bud earlier in the spring, retain foliage later in the fall, and grow larger in height and trunk diameter than seedlings originating from more northern sources (Wood et al., 1998).

\footnotetext{
Received for publication 18 Sept. 2008. Accepted for publication 9 Dec. 2008.

Mention of trade names or commercial products in this article is solely for the purpose of providing specific information and does not imply recommendation or endorsement by the U.S. Department of Agriculture.

${ }^{1}$ To whom reprint requests should be addressed; e-mailgvolk@lamar.colostate.edu.
}

To survive in the north, pecan trees must be adapted to withstand the onset of cold temperatures in the fall, to survive extremely cold temperatures in midwinter, and to begin growth only after the danger of a spring freeze is over. In the fall, families of seedlings in provenance orchards can be distinguished by the inception of dormancy with seedlings from southern sources retaining leaves longer in the fall than seedlings grown from northern sources. However, leaf drop is typically initiated for all seedlings after the first frost $\left(0{ }^{\circ} \mathrm{C}\right)$, which is received at the Brownwood, TX, worksite by 16 Nov. (5 of 10 years) and at the College Station, TX, worksite by 30 Nov.

The progression of pecan cultivars through winter dormancy has not been well characterized. When pecan seedlings grown from open-pollinated 'Dodd' seeds were given $900 \mathrm{~h}$ of chilling at $6{ }^{\circ} \mathrm{C}$ and were transferred to a greenhouse at $23{ }^{\circ} \mathrm{C}$, greater than $50 \%$ began growth within $80 \mathrm{~d}$ (Smith et al., 1992). Longer periods of chilling reduced time to and increased uniformity of budbreak. Seedlings chilled at $5{ }^{\circ} \mathrm{C}$ had higher levels of budbreak in both first and second lateral buds after $1000 \mathrm{~h}$ than seedlings chilled at either 1 or $9{ }^{\circ} \mathrm{C}$. All terminal buds broke at 1000, 1500, 2000, and $2500 \mathrm{~h}$ regardless of chilling temperature. However, first lateral buds receiving $1{ }^{\circ} \mathrm{C}$ chilling had the highest recorded levels of budbreak after 1500 and $2000 \mathrm{~h}$, whereas second lateral buds receiving $5{ }^{\circ} \mathrm{C}$ continued to show the highest levels of budbreak at those time periods. The severity of the winter may influence duration of dormancy to different degrees in different areas of a tree, influencing uniformity of budbreak within the canopy. Heating requirements for pecan budbreak have been identified for pecan cultivars that experience minimal chilling (Sparks, 1993). Northern cultivars have greater chilling requirements for budbreak than southern cultivars (Sparks, 1993, 2005; Wood et al., 1998).

Generally, seed development occurs faster and results in early seed maturation in ecotypes from northern latitudes (Daws and Pritchard, 2008; Sparks, 1991). Northern pecan parents have conferred that trait on their progeny in several cultivars such as 'Pawnee' (Thompson and Hunter, 1985), 'Osage' (Thompson et al., 1991), 'Kanza' (Thompson et al., 1997), and 'Lakota' (Thompson et al., 2008). Evaluating seasonal phenology of controlled cross-progeny families is easily done and is useful in predicting the extent to which a genotype fits a targeted environment, but more accurate methods of characterizing hardiness may improve the recognition of critical limitations and influence decisions of cultivar release and deployment.

Differential thermal analyses (DTA) have been used to imply cold hardiness in woody tissues of some species. In apple, pear, and azalea, a low temperature exotherm (LTE) of dormant woody stem sections, detected by DTA, correlated with injury to both xylem and pith that occurred during cooling (Graham and Mullin, 1976; Montano et al., 1987; Quamme et al., 1972a, 1972b). The LTE is an indication of the temperature at which supercooled water, presumably in the xylem, freezes. DTA profiles also show broad exothermic events at higher temperatures, which are usually interpreted as water freezing in extracellular spaces of the xylem and pith. The magnitude of the LTE decreases with slow cooling rates (less than $5{ }^{\circ} \mathrm{C} / \mathrm{h}$ ) or increased exposure times at subzero temperatures (Quamme et al., 1972a, 1972b, 1973). The correlation between LTE temperatures and mortality led some to suggest that the DTA technique could be used to indicate cold hardiness and Quamme (1991) proposed using LTE temperature as a measurement of cold hardiness in breeding programs for some species. LTE temperatures have previously been shown to correlate with lethal cooling in winter and early springharvested pecan apical floral buds and stem samples (Rajashekar and Reid, 1989).

Many factors contribute to cold hardiness in pecan trees: rootstock, crop load, tree age, nutritional status, seasonal growth and weather conditions, cultivar, and ecotype (Grauke and Pratt, 1992; Sanderlin, 2000; Smith, 2000, 2002; Smith et al., 2001; Sparks and Payne, 1977). Our interest here was to survey a broad range of pecan diversity (112 cultivars) to determine if differences in ecotype could be detected by LTE profile.

\section{Materials and Methods}

Plant material. Pecan dormant budwood was collected in 1998 and 1999 from the 


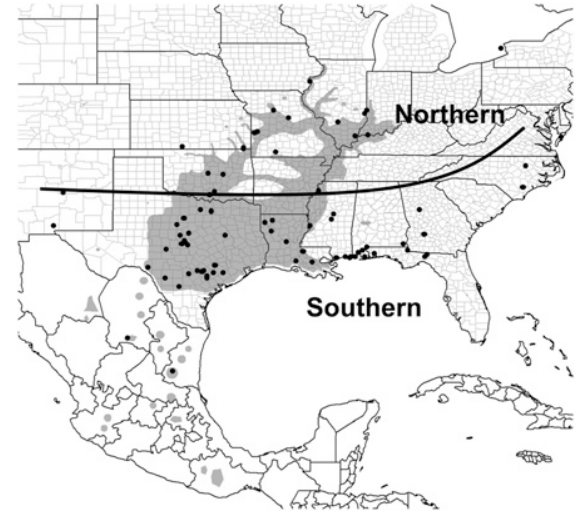

Fig. 1. Geographic origins of pecan cultivars included in 1999 differential thermal analyses. Shaded area indicates the native region of pecan. Latitude $34^{\circ} \mathrm{N}$ separates the southern region from the northern region for ecotype comparisons.

USDA-ARS National Collection of Genetic Resources in Brownwood and College Station, TX. Cultivars were grouped in relation to the latitude and longitude of their origin (Fig. 1). The two regions were generally consistent with boundaries of ecogeographic regions (Vogel et al., 2005). North latitude $34^{\circ}$ was selected as the division between the regions because it is the limit of Carya during the Pleistocene glaciation $\approx 16,000$ years ago. It is also close to the latitude $\left(36^{\circ}\right)$ defined for pecan trees that are adapted to a growing season of 210 or more days (Sparks, 1991).

The stage of budbreak was determined in early Apr. 2004 and 2005 at the College Station worksite. Budbreak was scored on a 1 to 9 scale from dormant to fully expanded (Grauke, 2008). Patterns of cultivar performance were similar for the 2 years and previous results suggest that the patterns of budbreak are consistent across many years (Grauke and Thompson, 1996).

Dormant budwood (moisture content between $40 \%$ and $47 \%$ fresh weight basis) was packaged in plastic bags with damp paper and sent overnight to the USDA-ARS National Center for Genetic Resources Preservation in Ft. Collins, CO, for DTA. Budwood was held in sealed plastic bags at $\approx-3{ }^{\circ} \mathrm{C}$ until analyses were performed. Three cultivars, Frutoso (state of Coahuila, Mexico), Burkett (Callahan County, TX), and Hodge (Clark County, IL), were collected in Dec. 1998, Jan. 1998, and Mar. 1999 from the Brownwood, TX, worksite and budwood was held in plastic bags at $-3{ }^{\circ} \mathrm{C}$ for 0,1 to 2 months, and 3 to 4 months after collection before LTE determination. Budwood for 112 diverse pecan cultivars was collected on 6 Jan. 1999 from the College Station worksite and changes of LTE profiles were compared for storage durations of 0 to 35,37 to 70,90 to 120 , and 150 to $181 \mathrm{~d}$.

For DTA, dormant budwood was prepared by drilling holes $1 \mathrm{~cm}$ deep into stem sections that were 2.5 to $3 \mathrm{~cm}$ in length and cut from the current season's growth at least 4 $\mathrm{cm}$ below the tip of the terminal bud. Sections were placed on four of five thermocouples (type T, 30 gauge) wired together in parallel in an aluminum block. The fifth thermocouple served as a reference and was covered with a mass of aluminum foil. The aluminum block assembly was placed in a Cryomed freezer (Cryomed, Mt. Clemens, MI) and cooled at $-0.2{ }^{\circ} \mathrm{C} / \mathrm{min}$ to at least $\approx 50{ }^{\circ} \mathrm{C}$ $\left(12^{\circ} \mathrm{C} / \mathrm{h}\right)$. Thermocouple voltages were monitored and recorded with a 12-bit data acquisition system (Intelligent Instrumentation, Tucson, AZ). LTE was detected as the temperature where the lowest peak began. DTA traces that did not produce significant LTE (the average slope of the DTA was less than $3 \times 10^{-6}$ volts $/{ }^{\circ} \mathrm{C}$ ) were considered "flat" traces. All DTA were performed at least twice for each cultivar. Analyses of variance were conducted to determine the main effects of LTE temperature, region of origin, and whether materials originated from wild or cultivated sources.

\section{Results and Discussion}

Sometimes cooling rates affect the shape of the LTE. However, in preliminary studies, the temperature of the onset of the LTE did not change when budwood was cooled at rates of $0.6,3.0,12$, or $24{ }^{\circ} \mathrm{C} / \mathrm{h}$ (data not shown; similar results reported by Rajashekar and Reid, 1989). In all subsequent analyses, a cooling rate of $12{ }^{\circ} \mathrm{C} / \mathrm{h}$ resulted in a first exotherm between -5 and $-10{ }^{\circ} \mathrm{C}$ representing extracellular water that froze as a result of spontaneous nucleation. These ranges are similar to that reported in the literature (Ketchie and Kammereck, 1987).

Low temperature exotherms and harvest date. The LTE was identified in DTA for cultivars Frutoso (Mexico), Burkett (Texas), and Hodge (Illinois) (Fig. 2). Budwood from the cultivars was harvested in December, January, and March and DTA were performed immediately, after 1 to 2 months, and after 3 to 4 months (Table 1). Initially, the LTE of 'Frutoso' was $-19{ }^{\circ} \mathrm{C}$ in December compared with significantly lower LTE

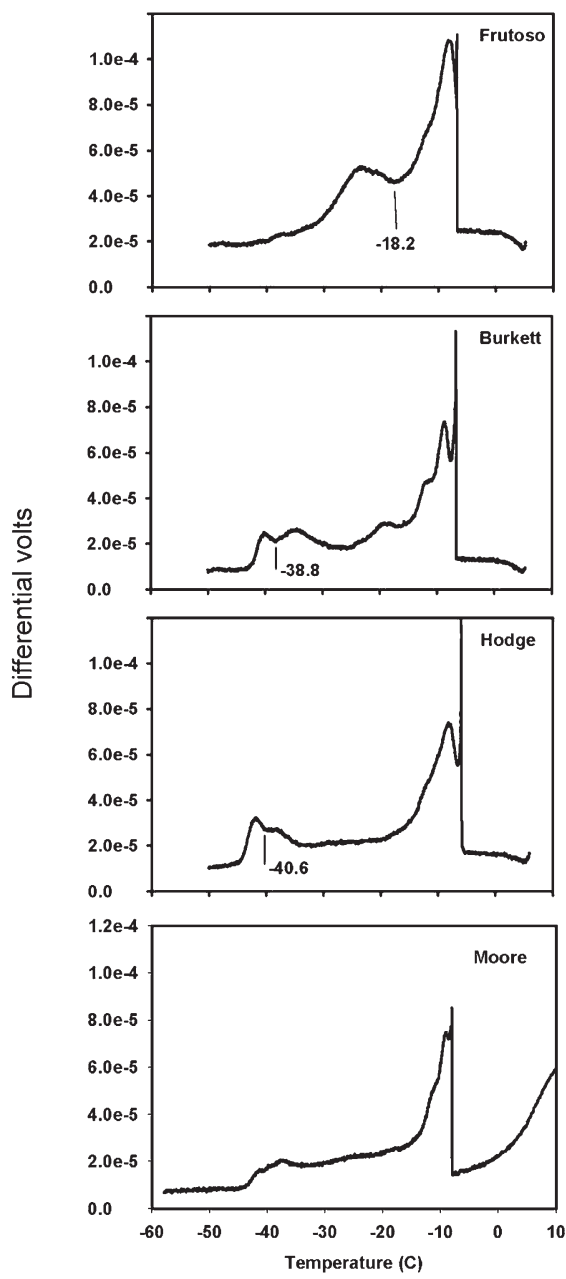

Fig. 2. Representative differential thermal analyses of fresh pecan twigs of 'Frutoso', 'Burkett', and 'Hodge' harvested in Dec. 1998 compared with a "flat" trace of 'Moore' harvested in Jan. 1999. Low temperature exotherms are identified on the traces.

of -39 and $-40{ }^{\circ} \mathrm{C}$ for 'Burkett' and 'Hodge', respectively. Both 'Hodge' and 'Burkett' retained low LTEs for at least 2 months after the December sampling time point. The LTE of 'Frutoso' was significantly lower when this cultivar was sampled in January and held for up to 4 months ( -28 to $\left.-31^{\circ} \mathrm{C}\right)$. The LTE of 'Burkett' was similar when it was sampled in January and held for up to 4 months $\left(-25\right.$ to $\left.-28^{\circ} \mathrm{C}\right)$, whereas the DTA of 'Hodge' was lower ( -32 to $-36{ }^{\circ} \mathrm{C}$ ). At the March sampling time point, the LTE for all three cultivars were significantly higher $\left(-16\right.$ to $\left.-23{ }^{\circ} \mathrm{C}\right)$ than their lowest LTE.

Table 1. Comparison of the onset of the low temperature exotherms (LTE) for three pecan cultivars harvested in Dec., Jan., or Mar. 1999 and held for up to 4 months at $-3{ }^{\circ} \mathrm{C}$ before differential thermal analyses. ${ }^{z}$

\begin{tabular}{|c|c|c|c|c|c|c|c|c|c|}
\hline \multirow[b]{2}{*}{ Collection mo. } & \multicolumn{3}{|c|}{ Frutoso, Mexico } & \multicolumn{3}{|c|}{ Burkett, TX } & \multicolumn{3}{|c|}{ Hodge, IL } \\
\hline & $0 \mathrm{mo}$ & $1-2 \mathrm{mo}$ & 3-4 mo & $0 \mathrm{mo}$ & $1-2 \mathrm{mo}$ & $3-4 \mathrm{mo}$ & $0 \mathrm{mo}$ & $1-2 \mathrm{mo}$ & $3-4 \mathrm{mo}$ \\
\hline Jan. & $\mathrm{n} / \mathrm{a}^{\mathrm{y}}$ & $-28 \pm 2.2$ & $-31 \pm 0.6$ & $\mathrm{n} / \mathrm{a}$ & $-28 \pm 0.1$ & $-25 \pm 4$ & $\mathrm{n} / \mathrm{a}$ & $-32 \pm 5$ & $-36 \pm 0.4$ \\
\hline
\end{tabular}

${ }^{\mathrm{z}}$ Mean LTE and SE are provided.

${ }^{y}$ Not analyzed. 
Table 2. Locality, temperature of the onset of the low temperature exotherm (LTE) ( \pm SE), and budbreak data for 112 pecan cultivars.

\begin{tabular}{|c|c|c|c|c|c|c|c|c|}
\hline \multirow[b]{2}{*}{ Plant ID } & \multirow{2}{*}{$\begin{array}{l}\text { Inventory } \\
\text { designation }\end{array}$} & \multirow{2}{*}{$\begin{array}{l}\text { Latitude } \\
{ }^{\circ} \mathrm{N}\end{array}$} & \multirow{2}{*}{$\begin{array}{l}\text { Longitude } \\
{ }^{\circ} \mathrm{W}\end{array}$} & \multirow[b]{2}{*}{ Region } & \multirow[b]{2}{*}{ Source } & \multirow{2}{*}{$\frac{\mathrm{LTE}\left({ }^{\circ} \mathrm{C}\right)}{1999}$} & & \\
\hline & & & & & & & 2004 & 2005 \\
\hline Alley & CSV5-3 & 30.433 & -88.533 & South & Seedling & Flat & 4.5 & 4 \\
\hline Apache & CSHQ 4.3-1 & 31.726 & -98.973 & South & Cross & $-31.2 \pm 0.5$ & 6.5 & 5 \\
\hline Baker & CSV5-4 & 32.615 & -93.287 & South & Seedling & Flat & 6 & 4.5 \\
\hline Barton & CSV5-6 & 31.726 & -98.973 & South & Cross & $-35.3 \pm 0.8$ & 4.5 & 3 \\
\hline Big Boy & CSV11-4 & 29.368 & -98.424 & South & Seedling & Flat & 7 & 6 \\
\hline BoltenS24 & CSV10-1 & 39.385 & -87.496 & North & Seedling & $-35.7 \pm 0.5$ & 6 & 4 \\
\hline Brake & CSV5-9 & 35.973 & -77.823 & South & Native & Flat & 7 & 4 \\
\hline Branch & CSV17-3 & 30.400 & -88.583 & South & Seedling & Flat & 5 & 4 \\
\hline Bridges & CSV11-6 & 33.291 & -97.694 & South & Seedling & $-33.6 \pm 0.2$ & 2 & 2 \\
\hline Buchel\#1 & CSV11-7 & 29.098 & -97.285 & South & Native & Flat & 6 & 4 \\
\hline Burkett & CSV11-3 & 32.374 & -99.162 & South & Native & $-28.4 \pm 0.6$ & 5.5 & 4.7 \\
\hline Caddo & CSHQ7.3-1 & 31.781 & -84.018 & South & Cross & $-33.5 \pm 0.1$ & 6 & 5 \\
\hline Cape Fear & CSV18-11 & 34.690 & -77.980 & South & Seedling & Flat & 6 & 4 \\
\hline Carden & CSV21-27 & 31.715 & -96.163 & South & Native & -33.11 .7 & 5 & 3 \\
\hline Carlson \#3 & CSV9-7 & 41.176 & -91.000 & North & Native & $-39.0 \pm 0.2$ & 5.5 & 4 \\
\hline Carole Leigh & CSV17-15 & 30.790 & -87.780 & South & Seedling & Flat & 6 & 4 \\
\hline Carter & CSV5-1 & 30.411 & -88.828 & South & Seedling & $-33.7 \pm 0.1$ & 5 & 3 \\
\hline Cherokee & CSHQ10.3-1 & 31.726 & -98.973 & South & Cross & Flat & 6 & 5 \\
\hline Chetopa & CSV9-4 & 37.023 & -95.046 & North & Native & $-33.1 \pm 1.2$ & 2 & 2 \\
\hline Chickasaw & CSHQ11.3-1 & 31.726 & -98.973 & South & Cross & Flat & 8 & 7 \\
\hline Chief & CSV9-2 & 37.806 & -88.262 & North & Native & $-34.8 \pm 0.5$ & 5 & 4 \\
\hline Choctaw & CSHQ2.3-1 & 31.726 & -98.973 & South & Cross & $-33.2 \pm 0.3$ & 5 & 4 \\
\hline Clark & CSV11-10 & 31.105 & -98.505 & South & Native & Flat & 4 & 2.5 \\
\hline Colby & CSV9-3 & 38.679 & -89.309 & North & Native & $-34.4 \pm 0.5$ & 4 & 2 \\
\hline Comanche & CSHQ1.3-1 & 31.726 & -98.973 & South & Cross & $-38.3 \pm 0.6$ & 5 & 4 \\
\hline Dependable & CSV6-2 & 30.411 & -88.828 & South & Cross & $-34.1 \pm 1.1$ & 4.5 & 3 \\
\hline Desirable & CSV5-2 & 30.411 & -88.828 & South & Cross & $-33.5 \pm 0.4$ & 6 & 4 \\
\hline Dixie & CSV17-11 & 30.790 & -87.780 & South & Seedling & Flat & 7 & 6 \\
\hline Elliott & CSV2-2 & 30.631 & -87.056 & South & Seedling & $-26.3 \pm 0.2$ & 6.5 & 6 \\
\hline Esnuel & CSV17-21 & 31.000 & -87.500 & South & Seedling & $-33.8 \pm 0.3$ & 7 & 5 \\
\hline Evans & CSV11-12 & 29.867 & -96.817 & South & Seedling & $-33.5 \pm 0.3$ & 5 & 3.5 \\
\hline Evers & CSV11-13 & 33.188 & -97.064 & South & Seedling & Flat & 7 & 6 \\
\hline EW 7-22 & CSV16-22 & 29.451 & -96.334 & South & Hybrid & Flat & 5 & 3 \\
\hline EW7-25 & CSV16-23 & 29.451 & -96.334 & South & Hybrid & $-33.2 \pm 0.0$ & 6 & 4 \\
\hline Farley & CSV6-5 & 30.800 & -85.020 & South & Seedling & Flat & 5 & 3 \\
\hline Fayette & CSV11-16 & 29.899 & -96.872 & South & Seedling & $-34.0 \pm 0.5$ & 4 & 4 \\
\hline Forkert & CSV5-5 & 30.411 & -88.828 & South & Cross & $-31.9 \pm 0.2$ & 5.5 & 3.5 \\
\hline Foster & CSV12-2 & 29.461 & -97.658 & South & Native & $-28.4 \pm 0.4$ & 6 & 5 \\
\hline Frutoso & CSV11-14 & 25.420 & -102.172 & South & Native & Flat & & \\
\hline Giles & CSV2-3 & 37.062 & -95.060 & North & Native & $-36.1 \pm 1.8$ & 3.5 & 2 \\
\hline Gormely & CSV12-6 & 35.433 & -96.305 & North & Native & $-35.4 \pm 0.3$ & 2.5 & 2 \\
\hline Govett & CSV12-7 & 29.568 & -97.885 & South & Native & $-34.4 \pm 0.4$ & 5.5 & 4.5 \\
\hline Greenriver & CSV19-12 & 37.899 & -87.482 & North & Native & $-37.9 \pm 1.4$ & 5.5 & 4.5 \\
\hline Hirschi & CSV19-14 & 38.064 & -94.238 & North & Native & $-34.7 \pm 0.9$ & 5 & 4 \\
\hline Hodge & CSV19-7 & 39.174 & -87.635 & North & Native & $-36.7 \pm 0.3$ & & \\
\hline Hollis & CSV12-13 & 31.100 & -98.514 & South & Native & Flat & 5 & 4 \\
\hline Hughes & CSV6-1 & 30.411 & -88.828 & South & Seedling & $-33.9 \pm 1.1$ & 5.5 & 4 \\
\hline Humble & CSV12-17 & 29.087 & -99.875 & South & Native & $-34.3 \pm 0.4$ & 7 & 6 \\
\hline Ideal & CSV12-18 & 32.763 & -98.718 & South & Native & Flat & 4 & 2 \\
\hline Jackson & CSV8-7 & 30.411 & -88.828 & South & Seedling & $-35.4 \pm 2.2$ & 3 & 2 \\
\hline James (LA) & CSV5-7 & 32.335 & -91.023 & South & Seedling & $-35.1 \pm 0.3$ & 5.5 & 5 \\
\hline Johnson(KS) & CSV12-20 & 37.176 & -98.820 & North & Native & $-32.6 \pm 0.0$ & 3 & 2 \\
\hline Jubilee & CSV8-15 & 30.417 & -87.667 & South & Seedling & Flat & 5 & 4 \\
\hline Kanza & CSHQ13-9 & 31.726 & -98.973 & South & Cross & $-33.8 \pm 0.2$ & 5 & 5 \\
\hline Kiowa & CSHQ13-3 & 31.726 & -98.973 & South & Cross & $-28.7 \pm 0.5$ & 6 & 4 \\
\hline Koko & CSV17-23 & 30.125 & -91.833 & South & Seedling & Flat & 6 & 4 \\
\hline Late & CSV13-3 & 31.374 & -98.677 & South & Native & $-37.0 \pm 0.9$ & 2 & 1 \\
\hline Longfellow & CSV13-4 & 31.193 & -98.847 & South & Native & $-26.2 \pm 0.3$ & 6 & 5 \\
\hline Mahan & CSV6-6 & 33.058 & -89.588 & South & Seedling & $-27.6 \pm 0.0$ & 7 & 6 \\
\hline Mahan-Stuart & CSV8-4 & 30.545 & -83.870 & South & Seedling & Flat & 6 & 4 \\
\hline McCulley & CSV21-4 & 31.723 & -98.958 & South & Native & $-34.8 \pm 0.9$ & 6 & 4 \\
\hline McMillan & CSV17-7 & 30.790 & -87.780 & South & Seedling & $-34.6 \pm 0.3$ & 4 & 4 \\
\hline Melrose & CSV17-22 & 31.961 & -93.348 & South & Seedling & Flat & 6 & 5 \\
\hline Mississippi 10 & CSV7-3 & 32.730 & -89.700 & South & Seedling & Flat & 2 & 2 \\
\hline MO-AES-2 & CSV19-13 & 38.959 & -92.343 & North & Native & $-39.2 \pm 0.6$ & 3 & 2 \\
\hline Mobile & CSV17-20 & 30.417 & -88.225 & South & Seedling & Flat & 6 & 4 \\
\hline Mohawk & CSHQ6.3-1 & 31.726 & -98.973 & South & Cross & Flat & 5 & 4 \\
\hline Moneymaker & CSV7-5 & 32.339 & -91.024 & South & Seedling & $-31.5 \pm 0.2$ & 7 & 6 \\
\hline Montgomery & CSV16-24 & 32.516 & -93.732 & South & Seedling & $-33.9 \pm 0.4$ & 3 & 2 \\
\hline Moore & CSV2-4 & 30.411 & -83.953 & South & Seedling & Flat & 6 & 5.5 \\
\hline MX5-1.7 & CSP16-9 & 23.405 & -99.381 & South & Native & Flat & & \\
\hline N1-62 & CSV11-19 & 32.300 & -106.700 & South & Cross & $-38.0 \pm 0.5$ & 5.5 & 4 \\
\hline $\mathrm{N} 2-43$ & CSV12-1 & 32.300 & -106.700 & South & Cross & Flat & 5 & 5 \\
\hline
\end{tabular}


Table 2. (Continued) Locality, temperature of the onset of the low temperature exotherm (LTE) ( \pm SE), and budbreak data for 112 pecan cultivars.

\begin{tabular}{|c|c|c|c|c|c|c|c|c|}
\hline \multirow[b]{2}{*}{ Plant ID } & \multirow{2}{*}{$\begin{array}{c}\text { Inventory } \\
\text { designation }\end{array}$} & \multirow{2}{*}{$\begin{array}{l}\text { Latitude } \\
{ }^{\circ} \mathrm{N}\end{array}$} & \multirow{2}{*}{$\begin{array}{l}\text { Longitude } \\
{ }^{\circ} \mathrm{W}\end{array}$} & \multirow[b]{2}{*}{ Region } & \multirow[b]{2}{*}{ Source } & \multirow{2}{*}{$\frac{\mathrm{LTE}\left({ }^{\circ} \mathrm{C}\right)}{1999}$} & \multicolumn{2}{|c|}{ Budbreak } \\
\hline & & & & & & & 2004 & 2005 \\
\hline Navaho & CSHQ13-8 & 31.726 & -98.973 & South & Cross & Flat & 8 & 7 \\
\hline $\mathrm{NC} 4$ & CSV19-15 & 43.200 & -79.300 & North & Seedling & $-37.9 \pm 0.1$ & 5 & 3 \\
\hline Nelson & CSV6-7 & 30.351 & -89.398 & South & Seedling & $-37.0 \pm 0.5$ & 7 & 6 \\
\hline Nugget & CSV13-7 & 31.837 & -98.396 & South & Native & $-26.9 \pm 1.2$ & 3.5 & 2.5 \\
\hline Number 54 & CSV13-5 & 34.360 & -106.100 & South & Cross & $-27.3 \pm 0.9$ & 6.5 & 5 \\
\hline Oconee & CSHQ13-7 & 31.726 & -98.973 & South & Cross & $-35.5 \pm 0.9$ & 5 & 4 \\
\hline Oklahoma & CSV13-9 & 34.174 & -97.143 & North & Seedling & $-26.9 \pm 0.2$ & 4 & 2.5 \\
\hline Oliver & CSV4-1 & 30.852 & -99.772 & South & Native & $-32.2 \pm 1.1$ & 5 & 4 \\
\hline Osage & CSHQ13-5 & 28.594 & -98.991 & South & Cross & $-34.4 \pm 0.1$ & 5 & 4 \\
\hline Owens & CSV8-1 & 34.440 & -90.495 & South & Seedling & $-36.3 \pm 0.1$ & 7 & 6 \\
\hline Pointe Coupee & CSV8-2 & 30.734 & -91.433 & South & Native & $-34.0 \pm 0.5$ & 7 & 5 \\
\hline Prilop & CSV14-17 & 29.424 & -96.940 & South & Native & $-38.7 \pm 0.4$ & 3 & 3 \\
\hline Ripe Early & CSV13-13 & 35.520 & -97.240 & North & Native & $-34.2 \pm 0.5$ & 6.5 & 5 \\
\hline Risien \#1 & CSV13-14 & 31.249 & -98.596 & South & Native & Flat & 6 & 5 \\
\hline Roth & CSV13-15 & 29.248 & -97.329 & South & Native & $-34.8 \pm 0.4$ & 6 & 4 \\
\hline San Felipe & CSV3-2 & 29.732 & -100.896 & South & Native & Flat & 4.5 & 3.5 \\
\hline Schaeffer & CSV7-4 & 30.411 & -88.828 & South & Seedling & $-35.6 \pm 0.3$ & 6 & 4 \\
\hline Schley & CSV6-11 & 30.366 & -88.556 & South & Seedling & Flat & 6 & 4 \\
\hline Schutz \#1 & CSV13-16 & 29.476 & -97.550 & South & Native & $-28.2 \pm 0.5$ & 2.5 & 2 \\
\hline Shawnee & CSHQ8.3-1 & 31.726 & -98.973 & South & Cross & Flat & 6 & 5 \\
\hline Shoshoni & CSHQ13-1 & 31.726 & -98.973 & South & Cross & $-30.1 \pm 1.9$ & 7 & 6 \\
\hline Sioux & CSHQ5.3-1 & 31.726 & -98.973 & South & Cross & $-32.7 \pm 0.1$ & 6 & 5 \\
\hline Spence (MO) & CSV9-16 & 36.825 & -93.130 & North & Native & $-34.3 \pm 0.6$ & 2 & 1 \\
\hline Squirrels Delight & CSV13-19 & 31.249 & -98.596 & South & Native & $-38.9 \pm 0.0$ & 5 & 4 \\
\hline Stuart & CSV7-6 & 30.366 & -88.556 & South & Seedling & $-31.0 \pm 1.4$ & 4 & 2 \\
\hline Surprize & CSV7-11 & 30.406 & -87.684 & South & Seedling & $-31.8 \pm 1.4$ & 6 & 4 \\
\hline Syrup Mill & CSV17-9 & 30.694 & -88.043 & South & Seedling & Flat & 7 & 6 \\
\hline Tejas & CSHQ13-2 & 31.726 & -98.973 & South & Cross & $-34.3 \pm 0.2$ & 6 & 4 \\
\hline Tinker & CSV17-19 & 31.180 & -85.280 & South & Seedling & $-34.7 \pm 0.2$ & 7 & 5 \\
\hline TSCN-88 & CSV14-12 & 29.522 & -97.491 & South & Native & Flat & 6 & 3 \\
\hline Van Deman & CSV3-3 & 30.087 & -90.905 & South & Seedling & $-30.1 \pm 1.7$ & 7 & 4 \\
\hline Wallops Island & CSV9-15 & 37.719 & -75.666 & South & Seedling & $-39.7 \pm 0.0$ & 3.5 & 3 \\
\hline Waukeenah & CSV3-5 & 30.411 & -83.953 & South & Seedling & $-26.1 \pm 0.2$ & 9 & 7 \\
\hline Weise & CSV20-4 & 39.386 & -93.221 & North & Native & $-34.8 \pm 0.7$ & 2 & 2 \\
\hline Wichita & CSHQ3.3-1 & 31.726 & -98.973 & South & Cross & $-31.0 \pm 1.7$ & 6 & 6 \\
\hline Williamson & CSV14-7 & 34.404 & -96.826 & North & Native & $-39.4 \pm 0.1$ & 3 & 2 \\
\hline Wilson & CSV15-12 & 38.000 & -94.392 & North & Hybrid & $-36.4 \pm 0.4$ & 3 & 2 \\
\hline Woodroof & CSV17-10 & 33.270 & -84.290 & South & Seedling & Flat & 7.5 & 6.5 \\
\hline Woodside Early & CSV7-1 & 31.311 & -92.445 & South & Seedling & $-26.5 \pm 0.3$ & 5 & 3 \\
\hline
\end{tabular}

Table 3. Average temperature of the onset of the low temperature exotherm (LTE) and budbreak classification for cultivars originating in the northern and southern regions. ${ }^{z}$

\begin{tabular}{lccccc}
\hline & Cultivars & Flat & & \multicolumn{2}{c}{ Budbreak } \\
\cline { 5 - 6 } Region & $\#$ & fraction & LTE $\left({ }^{\circ} \mathrm{C}\right)$ & 2004 & 2005 \\
\hline South & 93 & 0.39 & $-32.9 \pm 0.4 \mathrm{a}$ & $5.4 \pm 0.2 \mathrm{a}$ & $4.2 \pm 0.2 \mathrm{a}$ \\
North & 19 & 0.11 & $-35.4 \pm 0.7 \mathrm{~b}$ & $3.9 \pm 0.4 \mathrm{~b}$ & $2.7 \pm 0.3 \mathrm{~b}$ \\
\hline
\end{tabular}

${ }^{\mathrm{z}}$ Means and SEs are provided. Significant differences were identified using $t$ tests.

Letters represent significant differences between means as identified by a Tukey means separation test $(\alpha<0.05)$.

Some pecan DTA traces revealed multiple intermediate exotherms (Fig. 2). These exotherms may result from freezing events that occur in different tissue types within the dormant budwood (Ketchie and Kammereck, 1987), although these exotherms do not necessarily correlate with freezing injury (Quamme et al., 1972a). The presence of additional exotherms may be dependent on the phase of acclimation and the time of sampling (Ketchie and Kammereck, 1987; Quamme et al., 1972a). Multiple exotherms have been reported during deacclimation and may also represent the ability of tissue types to supercool. The multiple exotherms exhibited in pecan dormant budwood could indicate a lack of full acclimation attained by trees at the Texas sampling location. In contrast, a correlation was identified between pecan cultivars and the temperature of the
LTE in dormant budwood originating from Kansas and sampled in January (Rajashekar and Reid, 1989). The effectiveness of LTEs in predicting freezing injury appears to be dependent on sampling location.

Cultivar comparison. When all the cultivars collected from the College Station, TX, worksite with LTE were compared across the four storage time intervals, no significant changes in LTE occurred during storage until after $120 \mathrm{~d}$ of storage when the average LTE (if present) was significantly warmer (data not shown). In subsequent analyses, all data collected after $120 \mathrm{~d}$ of storage were not included in analyses. Pecan cultivars, seedlings, or breeding program crosses were classified according to their location of origin (Fig. 1). Inventories from the northern region had later budbreak times in both 2004 and 2005 than cultivars from the southern region
(Tables 2 and 3). Although all budwood was sampled from the College Station, TX, worksite, $39 \%$ of the cultivars originally from the southern regions had unresolved or "flat" LTE compared with $11 \%$ of the cultivars originally from the northern regions with flat LTE (Table 3). The flat LTE observed in the southern pecan materials may result from a reduced capacity for cold acclimation in materials that are not native to regions that experience severe cold temperatures. We believe that these flat LTE are distinctly different from the lack of LTE observed in extremely cold-hardy materials from northern regions (George et al., 1974). The lack of LTEs in some samples in the present study suggest that budwood did not become fully hardened in the Brownwood orchard at the January sampling date.

$t$ tests revealed significant differences among the LTEs of $-32.9^{\circ} \mathrm{C}$ from the southern region and the LTE of $-35.4{ }^{\circ} \mathrm{C}$ from the northern region, although all dormant budwood was collected from trees grown in College Station, TX. The northern region also had later budbreak in both 2004 and 2005 . Thus, DTA can be used to separate the more cold-hardy northern materials from the less hardy southern materials when accessions are grown in a common orchard (Table 3 ). 
Stem and apical floral bud LTEs could be correlated with killing temperatures in pecan (Rajashekar and Reid, 1989). Our xylem DTA data complement data previously published that suggest that LTEs occur at higher temperatures as pecan buds deharden in the spring (Rajashekar and Reid, 1989). However, LTEs were not observed for all accessions. Accessions native to the south were more likely to have flat traces that did not reveal useful exotherm data. These samples were likely not amenable to thermal analysis as a result of a lack of supercooled water detected by our DTA procedure.

Pecan cultivars were classified into improvement status categories of native, seedling, crosses, or hybrids (between different origin localities). It was hypothesized that named native cultivars that are clones of wild accessions native to the United States could have LTE more strongly correlated with origin locality than either seedlings or named cultivars from breeding programs. In our analyses, the temperature of LTE was not significantly affected by the improvement status of the pecan cultivars (data not shown).

Performance of two cultivars, Prilop and Nelson, is especially noteworthy. 'Nelson' is a Mississippi seedling selection made by William Nelson in 1904 (Nelson, 1904). Its tendency to break buds early in Brownwood was noted by Louis Romberg, the first pecan breeder in the USDA Agricultural Research Service (Romberg, 1966). 'Nelson' was rated at bud stages 7 and 6 in data reported here (Table 2). The early bud growth makes 'Nelson' very susceptible to late winter or early spring freezes, like the one experienced at Brownwood, TX, on 8 Apr. 2003. The tree was rated at bud stage 4 on 1 Apr. 2003 and was among the most severely damaged when temperatures dropped to $-2{ }^{\circ} \mathrm{C}$ for several hours. Shoots were killed back past the eighth bud of the previous season's growth but forced new growth with aberrant blooms. 'Prilop' is a native selection from the Lavaca River, originally growing $4 \mathrm{~km}$ south of Halletsville in Lavaca County, TX (Grauke and Thompson, 1997). The tree is unusually late in breaking buds in the spring as indicated by its rating of 3 in both years reported here (Table 2), making it comparable in phenology to many northern cultivars. 'Prilop' was not present in the Brownwood collection during the 2003 freeze. 'Nelson' and 'Prilop' had LTEs of -37 and $-38{ }^{\circ} \mathrm{C}$, respectively (Table 2), placing them in a category with the most hardy northern cultivars. Obviously, information provided by LTEs must be qualified by an understanding of cultivar phenology. At this time, the cost of LTE information is not justified by the quality of information it provides.
LTE data generally support recorded information about the relationship between hardiness and origin locality. Pecans that originated or were developed for more northerly localities are more likely to have discernible and lower LTE than those adapted to warmer southern climates. Because all the accessions used in comparisons were collected from common orchards, it is interesting that differences in LTE were observed. This suggests that the presence and extent of LTE have genetic components because all cultivars experienced similar winter acclimation conditions.

Both budbreak and LTE data are correlated to the region of origin and cultivars retain these properties when grown in a common environment. It follows that either phenotypic trait could be used as a possible predictor of origin and thus potential hardiness of uncharacterized cultivars. As a result of the relative ease of collecting budbreak data and the more challenging acquisition of DTA data, which is dependent on winter conditions, rootstock, and moisture content, it is suggested that budbreak data serve as a preliminary source of origin and potential hardiness of pecan cultivars.

\section{Literature Cited}

Daws, M.I. and H.W. Pritchard. 2008. The development and limits of freezing tolerance in Acer pseudoplatanus fruits across Europe is dependent on provenance. Cryo Letters 29:189-198.

George, M.F., M.J. Burke, H.M. Pellett, and A.G Johnson. 1974. Low temperature exotherms and woody plant distribution. HortScience 9:519-522.

Graham, P.R. and R. Mullin. 1976. The determination of lethal freezing temperatures in buds and stems of deciduous azalea by a freezing curve method. J. Amer. Soc. Hort. Sci. 101:3-7.

Grauke, L.J. 2008. Monitoring bud growth. 12 Sept. 2008. <http://extension-horticulture.tamu. edu/carya/Manual/BUDBRK.html $>$.

Grauke, L.J. and J.W. Pratt. 1992. Pecan bud growth and freeze damage are influenced by rootstock. J. Amer. Soc. Hort. Sci. 117:404-406.

Grauke, L.J. and T.E. Thompson. 1996. Variability in pecan flowering. Fruit Var. J. 50:140-150.

Grauke, L.J. and T.E. Thompson. 1997. Pecan. In: Register of new fruit and nut varieties. Brooks and Olmo, List 38. HortScience 32:793-796.

Grauke, L.J. and T.E. Thompson. 2008. Pecan, p. 421-425. In: Janick, J. and R.E. Paull (eds.) Encyclopedia of fruit and nuts. CAB International, Wallingford, UK.

Ketchie, D.O. and R. Kammereck. 1987. Seasonal variation of cold resistance in Malus woody tissue as determined by differential thermal analysis and viability tests. Can. J. Bot. 65 : 2640-2645.

Montano, J.M., M. Rebhuhn, K. Hummer, and H.B. Lagerstedt. 1987. Differential thermal analysis for large-scale evaluation of pear cold hardiness. HortScience 22:1335-1336.
Nelson, W. 1904. The Nelson pecan. The Nut Grower 2:134.

Quamme, H., C. Stushnoff, and C.J. Weiser. 1972a. The relationship of exotherms to cold injury in apple stem tissues. J. Amer. Soc. Hort. Sci. 97:608-613.

Quamme, H.A., C. Stushnoff, and C.J. Weiser. 1972b. Winter hardiness of several blueberry species and cultivars in Minnesota. HortScience 7:500-502.

Quamme, H., C.J. Weiser, and C. Stushnoff. 1973. The mechanism of freezing injury in xylem of winter apple twigs. Plant Physiol. 51:273277.

Quamme, H.A. 1991. Application of thermal analysis to breeding fruit crops for increased cold hardiness. HortScience 26:513-517.

Rajashekar, C.B. and W. Reid. 1989. Deep supercooling in stem and bud tissues of pecan. HortScience 24:348-350.

Romberg, L.D. 1966. Notes on varieties used in breeding of which progeny were fruited in the years through 1966. US Pecan Field Station, Brownwood, TX. Unpublished records. USDA-ARS.

Sanderlin, S. 2000. Pecan scion cultivar effects on freeze susceptibility of the rootstock. J. Amer. Pomological Soc. 54:188-193.

Smith, M.W. 2000. Cultivar and mulch affect cold injury of young pecan trees. J. Amer. Pomological Soc. 54:29-33.

Smith, M.W. 2002. Damage by early autumn freeze varies with pecan cultivar. HortScience 37:398-401

Smith, M.W., B.L. Carroll, and B.S. Cheary. 1992. Chilling requirement of pecan. J. Amer. Soc. Hort. Sci. 117:745-748.

Smith, M.W., B.S. Cheary, and B.L. Carroll. 2001. Rootstock and scion affect cold injury of young pecan trees. J. Amer. Pomological Soc. 55: 124-128.

Sparks, D. 1991. Geographical origin of pecan cultivars influences time required for fruit development and nut size. J. Amer. Soc. Hort. Sci. 116:627-631

Sparks, D. 1993. Chilling and heating model for pecan budbreak. J. Amer. Soc. Hort. Sci. 118: 29-35.

Sparks, D. 2005. Adaptability of pecan as a species. HortScience 40:1175-1189.

Sparks, D. and J.A. Payne. 1977. Freeze injury susceptibility of non-juvenile trunks in pecan. HortScience 12:497-498.

Thompson, T. and R.E. Hunter. 1985. 'Pawnee' pecan. HortScience 20:776

Thompson, T.E., L.J. Grauke, W. Reid, M.W. Smith, and S.R. Winter. 1997. 'Kanza' pecan. HortScience 32:139-140.

Thompson, T.E., W. Reid, and L.J. Grauke. 2008. 'Lakota' pecan. HortScience 43:250-251.

Thompson, T.E., E.F. Young, Jr., and H.D. Petersen. 1991. 'Osage' pecan. HortScience 26:10981099.

Vogel, K.P., M.R. Schmer, and R.B. Mitchell. 2005. Plant adaptation regions: Ecological and climatic classification of plant materials. Rangeland Ecol. Manag. 58:315-319.

Wood, B.W., L.J. Grauke, and J.A. Payne. 1998. Provenance variation in pecan. J. Amer. Soc. Hort. Sci. 123:1023-1028. 